Research Article

\title{
Nano-patents and Literature Frequency as Statistical Innovation Indicator for the use of Nano-porous Material in Three Major Sectors: Medicine, Energy and Environment
}

\author{
D. A. Gkika ${ }^{1,2, *}$, C. Kontogoulidou ${ }^{3}$, J. W. Nolan ${ }^{2}$, A. Ch. Mitropoulos ${ }^{2}$, E. F. Vansant ${ }^{4}$, P. Cool $^{4}$ and \\ J. Braet ${ }^{1}$
}

${ }^{1}$ University of Antwerp, Applied Economics, Department of Engineering Management, Antwerp, Belgium;

${ }^{2}$ Eastern Macedonia \& Thrace Institute of Technology, Hephaestus Advanced Laboratory, Kavala, Greece.

${ }^{3}$ University of Piraeus, Department of Business Administration, Piraeus, Greece.

${ }^{4}$ University of Antwerp, Department of Chemistry, Antwerp, Belgium.

Received 14 September 2015; Accepted 1 November 2016

\begin{abstract}
The statistical analysis of patents in specific areas can be an important tool for the evaluation of trends and advancements in specific research fields. Patenting is generally considered to be steered by commercial needs; hence it primarily concentrates on research results that are expected to have an important economic value. Patent data can be utilized to conduct comparative studies and trend analysis. This paper examines the granted patents from the United States Patent and Trademark office (USPTO) and the European Patent Office (EPO), in regards to the creation and/or use of nanoporous materials. The patents found were categorized by subject, and those belonging in the areas of Medicine, Energy or Environment were further analysed. The study also includes statistics about quality/value indicators, such as forward and backwards citations and references, age, family and materials used, as well as statistical data on the occurrences in literature of the materials studied, as found via a Scopus database search. The goal of this paper is to identify current trends and opportunities in these areas, and try to find possible gaps between the current reality and important societal needs. The identified trends and opportunities could be used by the industry as well as researchers, in order to adjust investment strategies, improve and potentially commercialize the corresponding patented applications.
\end{abstract}

Keywords: patents, porous materials, medicine, energy, environment,

\section{Introduction}

Porous materials are scientifically and technologically important materials due to the existence of voids (pores, cavities) the dimensions of which can be controlled at the nanometre, molecular and even atomic scales[1] facilitating their discrimination and interaction with molecules and clusters. Many natural porous materials (e.g. the clinoptilolite) [2] exist, but they can also be synthesised as well [3]. As already mentioned, the most important aspect of porous materials is the internal pore dimensions, or pore volume that can in some cases be designed [4], [5] or modified [6] for a specific application. The International Union of Pure and Applied Chemistry (IUPAC) categorises porous materials into three groups - micropores are less than $2 \mathrm{~nm}$ in diameter, mesopores are between 2 and $50 \mathrm{~nm}$, and macropores are greater than $50 \mathrm{~nm}$ in diameter. Although there is no standard definition of what a nanoporous material is, it is generally defined as being a porous material with pore diameters less than $100 \mathrm{~nm}$ [6].

Over the past ten years, there has been an incremental interest in nanoporous material research including synthesis, characterisation, modelling and design. The basic challenge is the understanding of the structure-property relation needed for the design/tailoring of nanoporous materials having

*E-mail address: despinagkika@gmail.com

ISSN: 1791-2377 @ 2016 Eastern Macedonia and Thrace Institute of Technology. All rights reserved. superior properties [7]. Most of the applications using nanoporous materials include -among others- sensors, safe energy storage, liquid and gas separations, inorganic membranes, catalysis, purifications, environmental issues (air, water, soil), and drug delivery

The aim of this work is to review what has been done so far in the application of nanoporous materials in energy, medicine and environment, in terms of granted patents, in order to find important and useful gaps.

Such a patent database search can be relatively easily performed by many, however this works aims to go a step further and evaluate the quality of the patents, as well as analyse them per category and materials used, which is important for the identification of trends and potential opportunities or gaps.

\section{Methodology}

Statistics can be very important when handling large amounts of data, such as patents, that need to be analysed. Patent documents include various types of data, such as text, numerical data, dates and images. They can provide significant insight into advancements being made in various fields. The methods used in this paper are briefly presented in Table 1.

The elimination of certain patent categories and the selection of specifically Medicine, Energy and Environment fields was done in order to focus on subjects that are of great 
interest to mankind and which are hence considered of higher societal priority.

Due to the studied patents being relatively new, it was decided that although certain indicators, such as basic family statistics should be recorded, further analysis of their family would be out of scope of this work.

Table 1. Statistics, statistical text mining, and text mining

\begin{tabular}{l|l|l}
\hline Statistics & $\begin{array}{l}\text { Statistical Text } \\
\text { Mining }\end{array}$ & Text mining \\
\cline { 2 - 3 } Sample Statistics & $\begin{array}{l}\text { Summary } \\
\text { Statistics }\end{array}$ & Query processing \\
$\begin{array}{l}\text { Graph and Table } \\
\text { creation }\end{array}$ & $\begin{array}{l}\text { Eliminating non } \\
\text { relevant patents }\end{array}$ & $\begin{array}{l}\text { Knowledge } \\
\text { Discovery } \\
\text { Information } \\
\text { retrieval }\end{array}$ \\
Ratent selection \\
Result Filtering & $\begin{array}{l}\text { Importing text data } \\
\text { Metadata } \\
\text { extraction }\end{array}$ & $\begin{array}{l}\text { Patent clustering } \\
\text { and categorization }\end{array}$ \\
\hline
\end{tabular}

The PATSTAT Online Information Service for Experts was used to retrieve a large number of patents from all over the world [8]. PATSTAT Online is a service provided specifically for statistical purposes and as their official description says "it is also known as the EPO Worldwide Patent Statistical Database, which is a snapshot of the EPO master documentation database (DOCDB) with worldwide coverage. It contains more than 20 tables with bibliographic data, citations and family links of about 70 million patents (granted, pending, expired, rejected etc.) of more than 80 countries."

Two patent searches were conducted, one to locate patents from the United States Patent Office (USPTO), and one from the European Patent Office (EPO). The USPTO office is the official office for the United States patents, while EPO is the European patent office. The service allows users to select the type of information they wish to find, as well as any filtering options, (i.e. per country, date, status and many others) using a database search query for that specific information. A query is a request for information from a database.

The query used for the USPTO patent search was the following: (TIEN $=*$ nanoporous $*$ or $\mathrm{TIEN}=*$ macroporous* or (TIEN=*porous* and TIEN $=*$ nano*) or TIEN $=*$ microporous $*$ or ${ }^{*}$ TIEN $=*$ mesoporous* $*$ or $\mathrm{ABEN}=*$ nanoporous* ${ }^{*}$ or $(\mathrm{ABEN}=*$ porous* $*$ and $\mathrm{ABEN}=*$ nano*) ${ }^{*}$ or $\mathrm{ABEN}=*$ macroporous* $*$ or $\mathrm{ABEN}=*$ microporous* $*$ or $\mathrm{ABEN}=*$ mesoporous $*$ ) and $\mathrm{PUD}[2010,2015]$ and $\mathrm{ISG}=\mathrm{YES}$ and $\mathrm{PUC}=\mathrm{US}$. The database for the USPTO patents was GPI v2015/27.

The search query used for the EPO patents was the following: (TIEN $=*$ nanoporous* or $\mathrm{TIEN}=*$ macroporous* or (TIEN $=*$ porous* and TIEN $=*$ nano*) ${ }^{*}$ or TIEN $=*$ microporous $*$ or $\quad$ TIEN $=*$ mesoporous* $*$ or $\mathrm{ABEN}=*$ nanoporous* $*$ or $(\mathrm{ABEN}=*$ porous* $*$ and $\mathrm{ABEN}=*$ nano* $)$ or $\mathrm{ABEN}=*$ macroporous $*$ or $\mathrm{ABEN}=$ *microporous* or $\mathrm{ABEN}=*$ mesoporous*) and PUD $[2010,2015]$ and $(\mathrm{PUK}=\mathrm{B} 1$ or $\mathrm{PUK}=\mathrm{B} 2)$.

The database for the EPO patents was EPAB v2015/27.
(TIEN=Title in English, ABEN=Abstract in English, $P U D=$ Publication Date, $P U C=$ Publication Country, $I S G=I S$ Granted, $P U K=$ Publication Kind Code)

Table 2. Patent Indicators [9]-[13]

\begin{tabular}{|c|c|c|c|}
\hline Indicator & Specification & Pros and Cons & Aim \\
\hline $\begin{array}{l}\text { Forward } \\
\text { Citations } \\
\text { Analysis }\end{array}$ & $\begin{array}{l}\text { A forward } \\
\text { citation of a } \\
\text { patent is a } \\
\text { patent's citation } \\
\text { back to the } \\
\text { original. }\end{array}$ & $\begin{array}{l}\text { Pros: they are a } \\
\text { good means of } \\
\text { evaluation, in the } \\
\text { notion that } \\
\text { frequently cited } \\
\text { patents are the } \\
\text { more important } \\
\text { ones } \\
\text { Cons: } \\
\text { Professionals } \\
\text { rarely use them to } \\
\text { estimate a patent's } \\
\text { value or quality. }\end{array}$ & $\begin{array}{l}\text { They imply } \\
\text { the patent is in } \\
\text { an active area } \\
\text { and indicate } \\
\text { relevance. }\end{array}$ \\
\hline $\begin{array}{l}\text { Backward } \\
\text { Citations } \\
\text { Analysis } \\
\text { (References } \\
\text { to other } \\
\text { patents) }\end{array}$ & $\begin{array}{l}\text { Backward } \\
\text { Citations are } \\
\text { references to } \\
\text { other patent } \\
\text { documents }\end{array}$ & $\begin{array}{l}\text { Pros: They can } \\
\text { reveal successful } \\
\text { technologies } \\
\text { Cons: A high } \\
\text { amount of } \\
\text { backward citations } \\
\text { could be } \\
\text { interpreted as } \\
\text { possible lack of } \\
\text { novelty. }\end{array}$ & $\begin{array}{l}\text { They can be } \\
\text { used as proof } \\
\text { of research to } \\
\text { examine prior } \\
\text { art. }\end{array}$ \\
\hline $\begin{array}{l}\text { Age of } \\
\text { Patent } \\
\text { (years) }\end{array}$ & $\begin{array}{l}\text { The age of a } \\
\text { patent since it } \\
\text { was granted }\end{array}$ & $\begin{array}{l}\text { Pros: Old age } \\
\text { might identify the } \\
\text { pioneers of a } \\
\text { certain technology } \\
\text { Cons: an old age } \\
\text { might mean that } \\
\text { the technology } \\
\text { used is possibly } \\
\text { outdated }\end{array}$ & $\begin{array}{l}\text { Can be used to } \\
\text { identify trends } \\
\text { over the years. }\end{array}$ \\
\hline $\begin{array}{l}\text { Patent } \\
\text { Family }\end{array}$ & $\begin{array}{l}\text { A "patent } \\
\text { family" usually } \\
\text { is defined as a } \\
\text { sum of all } \\
\text { patents } \\
\text { published in } \\
\text { various } \\
\text { countries that } \\
\text { are connected } \\
\text { directly or } \\
\text { indirectly to the } \\
\text { same } \\
\text { application. }\end{array}$ & $\begin{array}{l}\text { Pros: Can be used } \\
\text { to identify patent } \\
\text { value. } \\
\text { Cons: A family ID } \\
\text { can be used to } \\
\text { connect patent } \\
\text { documents that } \\
\text { have same scope } \\
\text { but don't share } \\
\text { priority. }\end{array}$ & $\begin{array}{l}\text { When there } \\
\text { are other } \\
\text { patents in the } \\
\text { family, then } \\
\text { that fact can } \\
\text { increase the } \\
\text { economic } \\
\text { value of a } \\
\text { patent. They } \\
\text { can also be } \\
\text { used as } \\
\text { building } \\
\text { blocks for } \\
\text { future analysis }\end{array}$ \\
\hline
\end{tabular}

These results were later filtered based on Patent category, and only those relevant to Medicine, Energy and Environment were included in the study.

From the various options provided for the patent search, Title and Abstract were the only ones selected, as opposed to including claims or teachings, because the majority of the results returned from such a query included patents that were irrelevant to the use or manufacture of nanotechnology products and/or porous materials, and only used the terms 
"nano" or "porous" arbitrarily or in references, thus affecting the final results negatively. This work makes the assumption that if a patent subject is truly related to the use or manufacturing of nanoporous materials there should at least be a mention of the term in its Title or Abstract.

Both queries were run on 08/07/2015. Basically the queries searched for all patents that have at least one of the words porous, nanoporous, macroporous, microporous or mesoporous in the English Title or the English Abstract and were issued between January 1st 2010 and 8th of July of 2015.

Table 3. Country rankings by total number of patent applications [8]

\begin{tabular}{|c|c|c|c|c|}
\hline \# & $\begin{array}{ll}\begin{array}{l}\text { Country } \\
\text { Office) }\end{array} & \text { (Patent } \\
\end{array}$ & $\begin{array}{l}\text { Country } \\
\text { Code }\end{array}$ & $\begin{array}{l}\text { Patent } \\
\text { Applications }\end{array}$ & $\begin{array}{l}\text { Ranking } \\
\text { (\%) }\end{array}$ \\
\hline 1 & China & $\mathrm{CN}$ & 5161 & 56.39 \\
\hline 2 & United States & US & 1052 & 11.49 \\
\hline 3 & Japan & JP & 896 & 9.79 \\
\hline 4 & Korea & $\mathrm{KR}$ & 542 & 5.92 \\
\hline 5 & European Patent Office & EP & 352 & 3.85 \\
\hline 6 & Russia & RU & 204 & 2.23 \\
\hline 7 & Canada & $\mathrm{CA}$ & 161 & 1.76 \\
\hline 8 & Taiwan & TW & 130 & 1.42 \\
\hline 9 & Spain & ES & 111 & 1.21 \\
\hline 10 & Austria & AT & 111 & 1.21 \\
\hline 11 & Australia & $\mathrm{AU}$ & 106 & 1.16 \\
\hline 12 & France & FR & 71 & 0.78 \\
\hline 13 & Denmark & DK & 40 & 0.44 \\
\hline 14 & Germany & $\mathrm{DE}$ & 32 & 0.35 \\
\hline 15 & Brazil & BR & 28 & 0.31 \\
\hline 16 & New Zealand & NZ & 26 & 0.28 \\
\hline 17 & Portugal & PT & 25 & 0.27 \\
\hline 18 & Ukraine & UA & 13 & 0.14 \\
\hline 19 & Great Britain & GB & 10 & 0.11 \\
\hline 20 & $\begin{array}{l}\text { Eurasian Patent } \\
\text { Organization }\end{array}$ & EA & 9 & 0.1 \\
\hline 21 & South Africa & ZA & 8 & 0.09 \\
\hline 22 & Norway & NO & 7 & 0.08 \\
\hline 23 & Morocco & MA & 7 & 0.08 \\
\hline 24 & Czech Republic & $\mathrm{CZ}$ & 7 & 0.08 \\
\hline 25 & Hungary & $\mathrm{HU}$ & 6 & 0.07 \\
\hline 26 & Egypt & EG & 6 & 0.07 \\
\hline 27 & Poland & PL & 5 & 0.05 \\
\hline 28 & Romania & RO & 4 & 0.04 \\
\hline 29 & Netherlands & NL & 3 & 0.03 \\
\hline 30 & Finland & FI & 3 & 0.03 \\
\hline 31 & Mexico & MX & 2 & 0.02 \\
\hline 32 & Luxembourg & LU & 2 & 0.02 \\
\hline 33 & Georgia & GE & 2 & 0.02 \\
\hline 34 & $\begin{array}{l}\text { African Regional } \\
\text { Industrial Property } \\
\text { Organization }\end{array}$ & AP & 2 & 0.02 \\
\hline 35 & San Marino & SM & 1 & 0.01 \\
\hline 36 & Slovakia & SK & 1 & 0.01 \\
\hline 37 & Republic of Moldova & MD & 1 & 0.01 \\
\hline 38 & Latvia & LV & 1 & 0.01 \\
\hline 39 & Lithuania & LT & 1 & 0.01 \\
\hline 40 & Iceland & IS & 1 & 0.01 \\
\hline 41 & Greece & GR & 1 & 0.01 \\
\hline 42 & Estonia & $\mathrm{EE}$ & 1 & 0.01 \\
\hline \multirow[t]{2}{*}{43} & Bulgaria & BG & 1 & 0.01 \\
\hline & Total & & 9153 & $100 \%$ \\
\hline
\end{tabular}

Both searches returned patents that were submitted in the two offices. They do not exclude patents from other countries. Therefore, there could be patents submitted in the USPTO by a European applicant, or a patent submitted in EPO by an American applicant.
The query for the USPTO patents includes only patents that were granted (using the ISG filter, i.e. it only returns patents that have been approved). Since the EPO database does not support this filter, the EPO query returned results for all types of patent applications (granted and not granted). In order to filter and keep only the granted ones, we used the Kind Code of the patents (PUK filter), and kept only those with Kind Code B1 or higher [14]. Kind codes are used to classify the status of a patent. A1 through A9 refer to applications, while B1 and higher refer to granted patents.

If a specific country is not specified in the search, the PATSTAT Online database returns results from all over the world. It is interesting to note that, as shown in Table 3, China has by far the most patent applications, followed by the US, Japan and then Korea. The ranking has been calculated as the amount of patent applications of one country divided by the sum of applications from all countries.

The EPO and USPTO offices originally used different classification systems for the various patents. EPO used the European CLAssification (ECLA) system and the USPTO used the United States Patent Classification (USPC) system. An effort was done to create a classification system that would harmonize and use the best practices of each of them, hence a new system, the Cooperative Patent Classification (CPC) was established. The shift to CPC was mainly done based on ECLA, and it was adjusted to ensure there was compatibility with the International Patent Classification system (IPC) standards as directed by the World Intellectual Property Organization (WIPO) [15].

The main criteria used in this study and for the evaluation of the patents are presented in table 2 and are further analysed below.

Forward Citations - They imply the patent is in an active area and indicate relevance. They were not truncated by years or other criteria. It should be noted that young patents might have fewer forward citations.

Backward Citations (References to other patents - local or international) - They prove that there was some research to examine prior art. According to most patent laws, prior art (also mentioned as background art or sometimes state of the art), refers to all information that has been released publicly in any form prior to a specific date that could be important in addressing a patent application's claims of originality.

Age - a patent that was filed early could potentially have more claims and value than those filed at a later time. On the other hand, an old age might also indicate that the technology used is possibly outdated.

Family - when there are other patents in the family, then that fact can increase the economic value of a patent.

The subject and categorization of each patent application were determined by studying the patent title, abstract and claims for each patent. Depending on the content of these, a category was assigned. The categories of interest for this study are Medicine, Environment and Energy. If a patent did not explicitly mention its use, or if it referred to some other than the above categories, then it was excluded. 
D. A. Gkika, C. Kontogoulidou, J. W. Nolan, A. Ch. Mitropoulos, E. F. Vansant, P. Cool and J. Braet /Journal of Engineering Science and Technology Review 9 (5) (2016) 24 - 35

Table 4. Patent classification rankings based on CPC group

\begin{tabular}{|c|c|c|c|}
\hline \# & CPC group & Patents & Ranking (\%) \\
\hline 1 & Y10T428 & 807 & 8.82 \\
\hline 2 & Y02E60 & 619 & 6.76 \\
\hline 3 & H01M2 & 603 & 6.59 \\
\hline 4 & B01D71 & 529 & 5.78 \\
\hline 5 & B01D67 & 457 & 4.99 \\
\hline 6 & H01M10 & 427 & 4.67 \\
\hline 7 & B01D69 & 424 & 4.63 \\
\hline 8 & B01D2325 & 400 & 4.37 \\
\hline 9 & B01J29 & 308 & 3.37 \\
\hline 10 & B01D2323 & 294 & 3.21 \\
\hline 11 & B01J35 & 280 & 3.06 \\
\hline 12 & C08J5 & 248 & 2.71 \\
\hline 13 & $\mathrm{~B} 01 \mathrm{~J} 20$ & 244 & 2.67 \\
\hline 14 & B01J37 & 238 & 2.6 \\
\hline 15 & B82Y30 & 227 & 2.48 \\
\hline 16 & B32B27 & 226 & 2.47 \\
\hline 17 & $\mathrm{C} 08 \mathrm{~J} 2323$ & 220 & 2.4 \\
\hline 18 & B29K2105 & 211 & 2.31 \\
\hline 19 & B29C55 & 203 & 2.22 \\
\hline 20 & B01D53 & 182 & 1.99 \\
\hline 21 & H01M4 & 181 & 1.98 \\
\hline 22 & $\mathrm{~B} 01 \mathrm{~J} 23$ & 179 & 1.96 \\
\hline 23 & C01B37 & 171 & 1.87 \\
\hline 24 & B01J21 & 169 & 1.85 \\
\hline 25 & H01M8 & 168 & 1.84 \\
\hline 26 & B29K2023 & 166 & 1.81 \\
\hline 27 & B01J2229 & 162 & 1.77 \\
\hline 28 & C01B39 & 159 & 1.74 \\
\hline 29 & C08J9 & 154 & 1.68 \\
\hline 30 & Y02W10 & 147 & 1.61 \\
\hline 31 & $\mathrm{C} 02 \mathrm{~F} 1$ & 131 & 1.43 \\
\hline 32 & Y02T10 & 128 & 1.4 \\
\hline 33 & B32B5 & 118 & 1.29 \\
\hline 34 & B01D61 & 117 & 1.28 \\
\hline 35 & C08L23 & 116 & 1.27 \\
\hline 36 & C01P2006 & 112 & 1.22 \\
\hline 37 & B29C47 & 111 & 1.21 \\
\hline 38 & Y10S977 & 104 & 1.14 \\
\hline 39 & C01B31 & 104 & 1.14 \\
\hline 40 & C04B2111 & 98 & 1.07 \\
\hline 41 & B01D2257 & 96 & 1.05 \\
\hline 42 & C10G2400 & 93 & 1.02 \\
\hline 43 & H01G9 & 90 & 0.98 \\
\hline 44 & A61L27 & 87 & 0.95 \\
\hline 45 & A61K9 & 87 & 0.95 \\
\hline 46 & C10G2300 & 83 & 0.91 \\
\hline 47 & C04B35 & 81 & 0.88 \\
\hline 48 & C01B33 & 80 & 0.87 \\
\hline 49 & B32B2307 & 79 & 0.86 \\
\hline 50 & G01N33 & 78 & 0.85 \\
\hline
\end{tabular}

\section{Results and Discussion}

The USPTO patent search returned 1360 patents involving porous, nanoporous, microporous, mesoporous and macroporous materials in the past 5 years. After filtering these results based on category, 463 were selected in total. From those, 258 were in the energy category, 51 in environment and 154 were medicine related. The results, presented per category and per year, are presented in table 5 .

The EPO search returned 169 patents initially, and after filtering for categories, 35 remained. Out of these, 23 belong in the energy category, 1 in the environment category and 11 are medicine-related. The EPO results are presented in table 6. Comparative results can be seen in figure 1 .
Table 5. USPTO Patents per category and year

\begin{tabular}{l|c|c|c|c|c|c|c}
\hline Category/Year & $\mathbf{2 0 1 0}$ & $\mathbf{2 0 1 1}$ & $\mathbf{2 0 1 2}$ & $\mathbf{2 0 1 3}$ & $\mathbf{2 0 1 4}$ & $\begin{array}{c}\mathbf{2 0 1 5} \\
\text { (till } \\
\text { July) }\end{array}$ & Total \\
\hline Medicine & 21 & 19 & 25 & 31 & 41 & 17 & $\mathbf{1 5 4}$ \\
Energy & 32 & 41 & 38 & 54 & 54 & 39 & $\mathbf{2 5 8}$ \\
Environment & 11 & 3 & 12 & 10 & 11 & 4 & $\mathbf{5 1}$ \\
\hline Total & $\mathbf{6 4}$ & $\mathbf{6 3}$ & $\mathbf{7 5}$ & $\mathbf{9 5}$ & $\mathbf{1 0 6}$ & $\mathbf{6 0}$ & $\mathbf{4 6 3}$ \\
\hline
\end{tabular}

Table 7 presents a breakdown of the USPTO results per country, identifying the US as the main contributor to the office over the specified time period, followed by Japan and Korea. The EPO search showed that most of the EPO patents are from Japan, followed by the US and Germany (table 8). From inside the EU, Germany, France and Belgium appear to be the most active countries.

Table 6. EPO Patents per category and year

\begin{tabular}{|c|c|c|c|c|c|c|c|}
\hline Category/Year & 2010 & 2011 & 2012 & 2013 & 2014 & $\begin{array}{c}2015 \\
\text { (till } \\
\text { July) }\end{array}$ & Total \\
\hline Medicine & 2 & 3 & 1 & 3 & 2 & 0 & 11 \\
\hline Energy & 1 & 2 & 4 & 7 & 5 & 4 & 23 \\
\hline Environment & 0 & 1 & 0 & 0 & 0 & 0 & 1 \\
\hline Total & 3 & 6 & 5 & 10 & 7 & 4 & 35 \\
\hline
\end{tabular}

Patents from both the UPSTO and EPO offices were collected and analysed based on country of origin and category, as well as terms used in their contents.

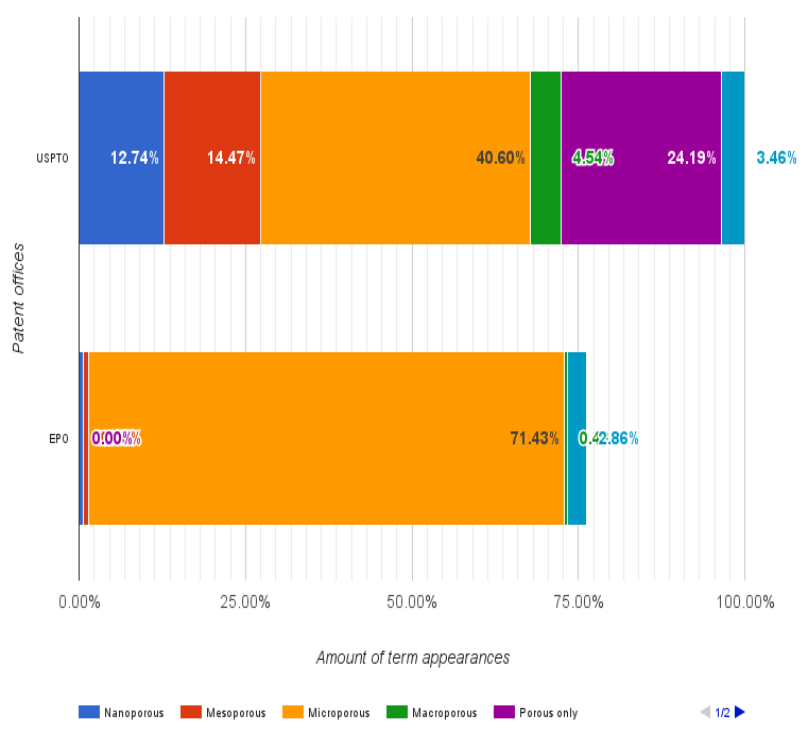

Fig. 1 Distribution of results per office, based on the appearance of the search terms in the English title or abstract of the paten 
Table 7. Patent Applicant Country per year \& total $\mathrm{USPTO}^{1 *}$

\begin{tabular}{|c|c|c|c|c|c|c|c|}
\hline Applicant country & 2010 & 2011 & 2012 & 2013 & 2014 & 2015 & Total \\
\hline United States & 42 & 22 & 37 & 49 & 48 & 30 & 228 \\
\hline Japan & 8 & 16 & 8 & 12 & 18 & 8 & 70 \\
\hline Korea & 7 & 16 & 9 & 10 & 9 & 10 & 61 \\
\hline Taiwan & & 3 & 5 & 2 & 4 & 2 & 16 \\
\hline China & 2 & & 2 & 5 & 3 & 1 & 13 \\
\hline Germany & & 2 & 3 & 3 & 3 & 2 & 13 \\
\hline France & & 2 & 2 & 3 & 2 & 1 & 10 \\
\hline Canada & 4 & 1 & 1 & & 3 & & 9 \\
\hline Great Britain & & & 2 & 3 & 2 & & 7 \\
\hline Singapour & & & 1 & 2 & 1 & 1 & 5 \\
\hline Belgium & 1 & & 2 & & 1 & & 4 \\
\hline Italy & & & 1 & 1 & 1 & 1 & 4 \\
\hline Netherlands & & & 1 & 1 & 1 & 1 & 4 \\
\hline Israel & & & & & 2 & 1 & 3 \\
\hline Sweden & & 1 & & 1 & 1 & & 3 \\
\hline Switzerland & & & & & 1 & 1 & 2 \\
\hline Hong Kong & & & & & 1 & 1 & 2 \\
\hline Australia & & & & 1 & & & 1 \\
\hline Bulgaria & & & & & 1 & & 1 \\
\hline Brazil & & & & & 1 & & 1 \\
\hline Chech Republic & & & & & 1 & & 1 \\
\hline Denmark & & & & & 1 & & 1 \\
\hline Estonia & & & & 1 & & & 1 \\
\hline Spain & & & & & 1 & & 1 \\
\hline India & & & & 1 & & & 1 \\
\hline Uzbekistan & & & 1 & & & & 1 \\
\hline
\end{tabular}

The initial results show that the most popular category of patents is Energy, followed by Medicine and Environment. For both offices, most patents originate from Japan and the US, followed by Taiwan, Korea and Germany. The vast majority of the patents was returned for the term "microporous" in their Title or Abstract.

Table 8. Patent Applicant Country per year and total - EPO

\begin{tabular}{l|c|c|c|c|c|c|c}
\hline Applicant country & $\mathbf{2 0 1 0}$ & $\mathbf{2 0 1 1}$ & $\mathbf{2 0 1 2}$ & $\mathbf{2 0 1 3}$ & $\mathbf{2 0 1 4}$ & $\mathbf{2 0 1 5}$ & Total \\
\hline Japan & 1 & 2 & 4 & 7 & 5 & 2 & 21 \\
United States & 1 & 2 & & 1 & 1 & & 5 \\
Germany & & 1 & & & & 2 & 3 \\
Barbados & 1 & 1 & 1 & & 1 & & 3 \\
France & & & & & & 1 \\
Belgium & & & & 1 & & & 1 \\
Brazil & & & & 1 & & & 1 \\
\hline
\end{tabular}

\footnotetext{
${ }^{1 *}$ some patents had applicants from multiple countries
}

\section{Forward Citations Analysis}

With regard to forward citations (references made to a patent in the description/details of another patent), it was observed that out of the 463 patents from USPTO, 332 have been cited by other patents. 112 of those are in the medicine category, while 189 are in energy, and 31 in environment. (Figure 2). For the EPO patents, the amount of them cited in other patents drops to only 10 out of 35 . (Figure 3 ).

The above results suggest that only a small amount of patents in the field are cited by other patent documents. Those that are cited though, especially those with multiple citations, indicate a lot of interest in their particular areas; in the US patents, this is mostly about batteries and nanowires, while in the EPO patents, this is in energy adsorption and batteries. The higher number of citations in the USPTO patents can indicate that the patent holders are more active in their own area of expertise, or that the cited patents are significant in their field, acting as a basis for other patented applications.

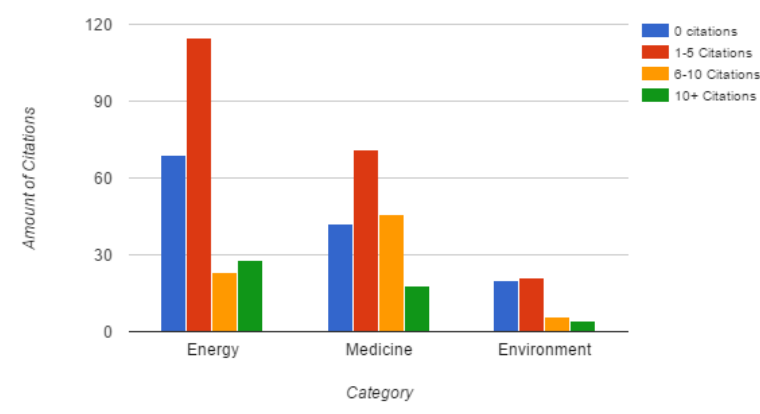

Fig. 2. USPTO Forward Citations Analytics

The forward citation analysis has shown that only a limited percentage of patents are cited by other patents. USPTO patents tend to be cited more than the EPO ones, but for both offices, it appears that most of the frequently cited patents are Energy related.

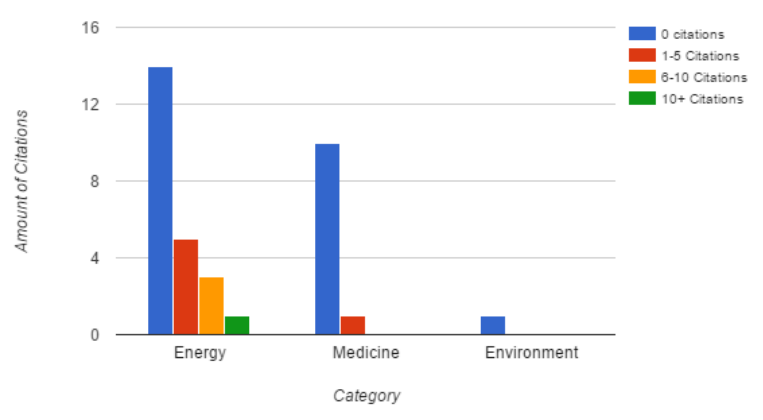

Fig. 3. EPO Forward Citation Analytics

\section{Backward Citations Analysis (References to other} patents)

Although forward citations are often considered as a more important indicator, backward citations can also provide information about the quality or value of a patent. They also 
indicate that the patent holder has made the appropriate research prior to submitting their own patent. ${ }^{2}$

Contrary to the low amount of forward citations found for the examined patents, it appears that almost all of the USPTO patents found in this study have made backward citations to other patents.

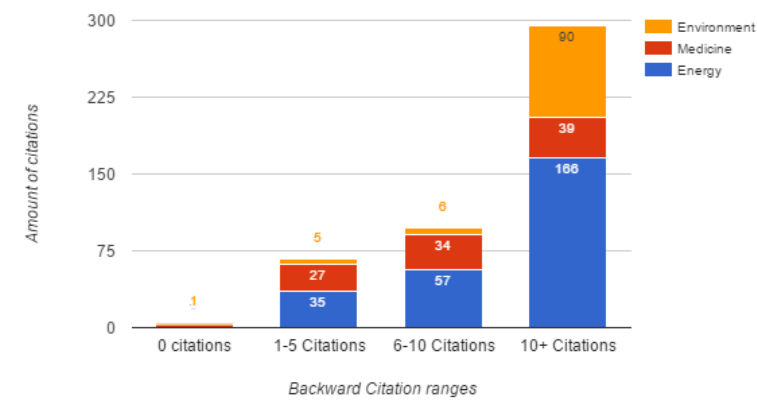

Fig. 4. USPTO Backward Citation Analytics - per patent category

The results show that more than $63 \%$ of the USPTO patents have more than 10 references to other patents, and $21 \%$ have at least 6-10 citations (figure 4). This also indicates that the majority of the patents with lots of backwards citations are energy-related, followed by those patents in the environment category.

The EPO patents contain fewer references to other patents. More specifically, 27 out of 35 patents have references to other patents, while the maximum amount of these references does not exceed 16 . Only 5 patents out of these have more than 10 references and 7 have more than 5 . The others have only 1-5 backward citations. This means that $32 \%$ of the EPO patents have no backward citations at all (figure 5).

The difference between USPTO and EPO patents is an indication that the USPTO patent holders appear to have made far more extensive research to prior work.

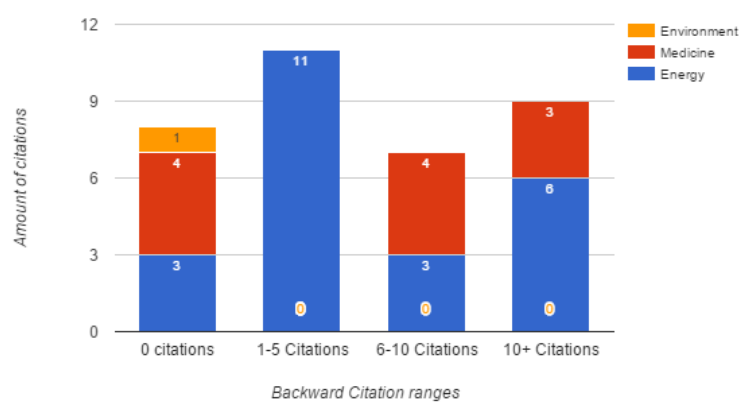

Fig. 5. EPO Backward Citation Analytics - per patent category

\footnotetext{
${ }^{2}$ Although backward citations are an important factor, there are cases that their absence does not necessarily diminish the value of the patent. When reviewing innovative applications there are top class patents that have little to none backward citation a fact which does not affect the final value.
}

The Backward Citation analysis has shown that almost the entirety of USPTO patents has backward citations, and most of them have more than 10 backward citations. The EPO patents on the other hand have less backward citations, and about $32 \%$ of them have none at all.

\section{Age of Patent (years)}

The age of a patent can be indicative of its significance, but can also provide information about the patent trends over the years. The age of the patents was calculated by subtracting the Publication Date of the patent from the date of the database search query $(8 / 7 / 2015)$. Therefore, a patent that was published for example on January 2015 or September 2014 belongs in the category of $<1$ year of age, while a patent published on June 2014 belongs to the category of 1 year. The age can also help calculate when a patent should be renewed or maintained, and when it expires. The term of a patent, for both the US and Europe, is set at 20 years. During that period, the holder has to pay renewal fees; otherwise the patent will expire before the term ends. The renewal dates are different for each country, and can vary from yearly to every 5 years. [16]

The results illustrate the trends for each office in a clearer manner: for USPTO, it appears that energy related patents have the tendency to increase in numbers, followed by medicine, while the environment related patents have remained in much lower levels (figure 6). For EPO the interest in medicine appears to be at lower levels and generally mostly stable or slightly declining, while the amount of environmental-related granted patents is almost non-existent (figure 7).

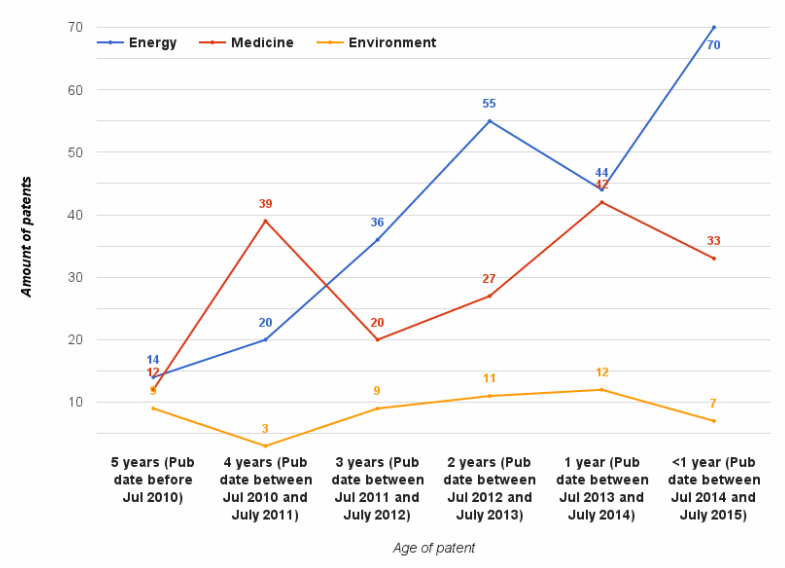

Fig. 6. Amount of USPTO patents per category based on patent age

When examining the trends per category for all the patent offices in total, it is noted that while energy oriented patents are clearly rising, environment and medicine related ones have shown a slight decrease in the last year, compared to those in the previous years (figure 8).

The patent age analysis shows that for USPTO, Energy is a category that shows constant development, followed by Medicine. For EPO, Energy related patents show a rise as well, although they reached their max about 1 year ago. In general, for both offices, it appears that Energy is the most popular category, while Medicine and Environment appear to have slight losses over the past year. 


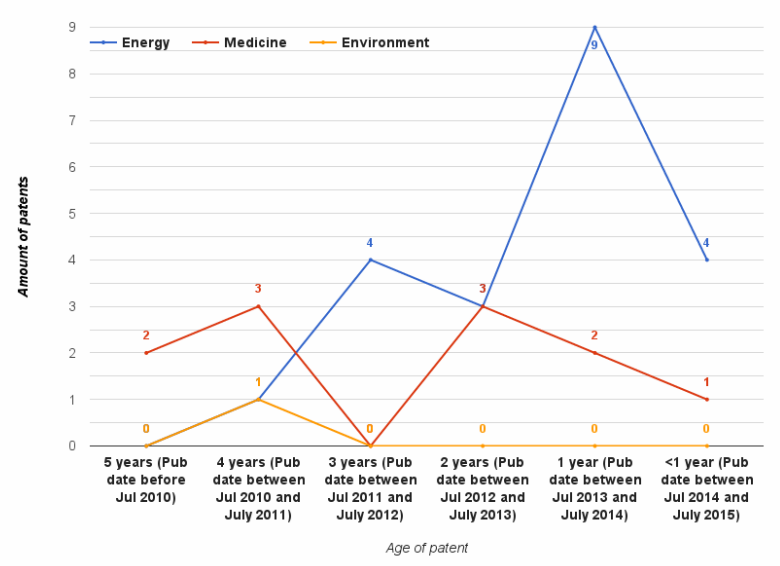

Fig. 7. Amount of EPO patents per category based on patent age

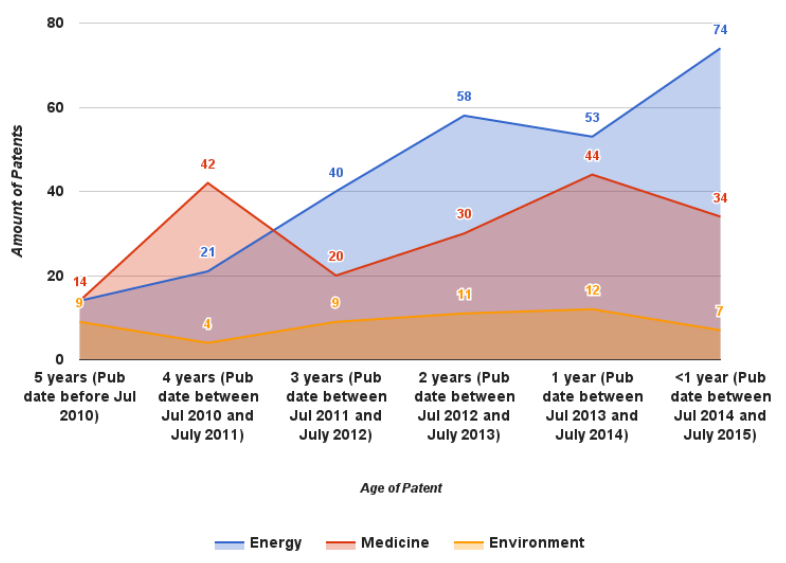

Fig. 8. Patents per category based on age (all offices)

\section{Patent Family}

Besides the main characteristics of patents, patent offices also offer additional information such as the family ID of a patent. Usually, a patent that belongs in a family is considered easier to sell as part of a portfolio[17]. The Inpadoc patent family scheme will be used for the patents in this study, which defines the family as follows: "all the documents directly or indirectly linked via a priority document belong to one patent family" [18]

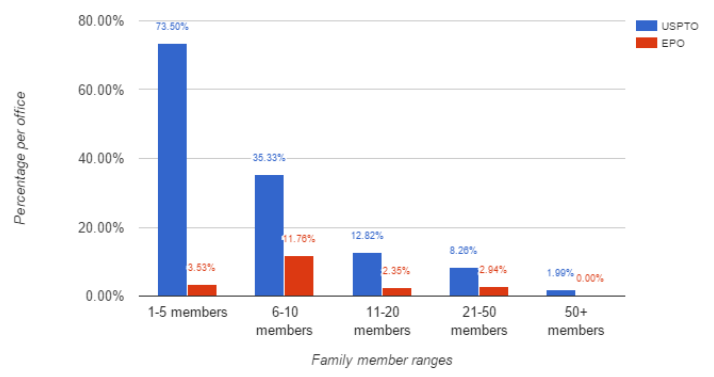

Fig. 9. Patent family members per office
It appears that the USPTO patents have generally more registered patents in the extended family (national application numbers, international application numbers and domestic relations are included in the family search). In total, though, the majority of patents have 1-10 family members, while there is a small amount of patents with more than 50 family members (figure 9).

The patent family analysis shows that the majority of patents in both offices belong in a family of 1 to 10 members. USPTO patents tend to have more family members in general.

\section{Most commonly referenced materials}

When it comes to materials, some patents reference specific names of materials, while others only mention a broader category (for example "nanoporous membrane"). Some materials come with different pore sizes, so for example "microporous carbon" is counted as a different material than "macroporous carbon".

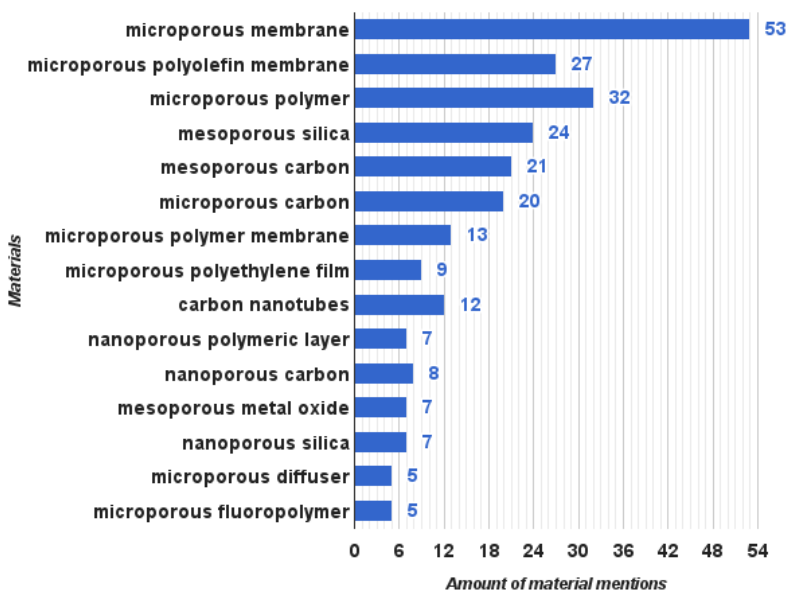

Fig. 10. Materials used with USPTO patents

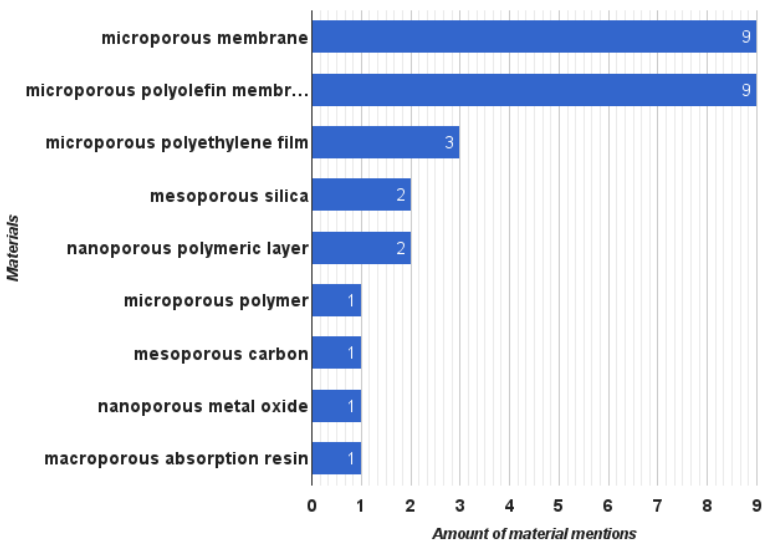

Fig. 11. Materials used with EPO patents

The most frequently mentioned materials in the USPTO patents are generic microporous membranes, followed by microporous polymers and microporous polyolefin membranes. For EPO, the most commonly used are generic microporous membranes, microporous polyolefin membranes followed by microporous polyethylene films. More details can be seen in figures 10 and 11 respectively. 
The results of the materials analysis indicate that the generic microporous membranes and the microporous polyolefin membranes are the most used materials in total, followed by microporous polymers and mesoporous silica.

\section{Nanoporous materials applications Key Enabling Technologies (KETs)}

Based on the European commission definition, Key Enabling Technologies (KETs) comprise micro and nanoelectronics, nanotechnology, industrial biotechnology, advanced materials, photonics, and advanced manufacturing technologies [19].

There is an ever-increasing interest in nanoporous materials, due to the many applications that can benefit from the controlled porosity at the nanoscale level. Even though various methods exist for laboratory scale synthesis of nanomaterials, scaling up for industrial use in terms of quantity, quality and costs, still remains a challenge [20].

In order to address this challenge, the Horizon 2020 programme has issued a call for proposals that would help bridge the gap between nanotechnology research and the market. The scope of the proposals should be to "address the development and demonstration in relevant industrial environments of reliable processes control and manufacturing routes, to obtain nanoporous materials with controlled pore distribution or gradient aiming at improved mechanical properties, reliable permeation rate, and different electrical properties, anti-fouling or other bio-, and photo- or thermo-chemical/physical properties [20].

\section{Market Evolution and example applications}

Although there are plenty of exciting advances in the field, so far nanotechnology-based products make use of only very basic nanostructures. The value of these items is not necessarily calculated based on the value of the nanomaterials, but on the value of the final product. Many products labelled as nanoproducts would still exist without the nanotechnology; however, there are some, such as pharmaceutical drugs that actually depend on nanomaterials, which could be exempted from the above. In general, though, most products have not reached a revolutionary stage. We can generally categorize the products based on their generation [21][22]. The First Generation (2000-2005): passive structures, particles, polymers and ceramics, carbon nanotubes and others. Then came the Second Generation (2005-2010): active structures, transistors, targeted drugs, sensors and others, which was followed by the Third Generation (2010-2015): 3D nanosystems, multiscale architectures, complex systems. The Fourth (and current) Generation (2015-2020): heterogenous molecular systems, molecules used as devices and new functions.

\section{West vs. East}

The Patent Applicant Country analysis, revealed that the US, Japan, Korea, Taiwan and Germany are the top countries that have contributed the most patents in both offices. When comparing the countries for trends, it was noted that the US has the most patents in all categories. Patents from Japan, Korea, Taiwan and Germany also focus mainly in the area of Energy, while Korea is in second place regarding patents on Medicine. The US is by far higher than all other countries regarding environment-related patents. Table 10 shows the results per category and year for each country, summed up for both USPTO and EPO.

Table 10. Results per category and year for each country, summed up for both EPO and USPTO

\begin{tabular}{|c|c|c|c|c|c|c|c|}
\hline \multicolumn{8}{|c|}{ USA } \\
\hline & 2010 & 2011 & 2012 & 2013 & 2014 & 2015 & Total \\
\hline Medicine & 16 & 14 & 11 & 17 & 21 & 11 & 90 \\
\hline Energy & 17 & 7 & 15 & 27 & 24 & 17 & 107 \\
\hline Environment & 10 & 3 & 11 & 6 & 4 & 2 & 36 \\
\hline Total & 43 & 24 & 37 & 50 & 49 & 30 & 233 \\
\hline \multicolumn{8}{|c|}{ Japan } \\
\hline & 2010 & 2011 & 2012 & 2013 & 2014 & 2015 & Total \\
\hline Medicine & 0 & 1 & 0 & 0 & 0 & 0 & 1 \\
\hline Energy & 9 & 17 & 12 & 18 & 21 & 10 & 87 \\
\hline Environment & 0 & 0 & 0 & 1 & 2 & 0 & 3 \\
\hline Total & 9 & 18 & 12 & 19 & 23 & 10 & 91 \\
\hline \multicolumn{8}{|c|}{ Korea } \\
\hline & 2010 & 2011 & 2012 & 2013 & 2014 & 2015 & Total \\
\hline Medicine & 1 & 4 & 2 & 0 & 0 & 2 & 9 \\
\hline Energy & 6 & 12 & 7 & 10 & 7 & 8 & 50 \\
\hline Environment & 0 & 0 & 0 & 0 & 2 & 0 & 2 \\
\hline Total & 7 & 16 & 9 & 10 & 9 & 10 & 61 \\
\hline \multicolumn{8}{|c|}{ Taiwan } \\
\hline & 2010 & 2011 & 2012 & 2013 & 2014 & 2015 & Total \\
\hline Medicine & 0 & 0 & 0 & 2 & 4 & 0 & 6 \\
\hline Energy & 0 & 3 & 5 & 0 & 0 & 2 & 10 \\
\hline Environment & 0 & 0 & 0 & 0 & 0 & 0 & $\mathbf{0}$ \\
\hline Total & $\mathbf{0}$ & 3 & 5 & 2 & 4 & 2 & 16 \\
\hline \multicolumn{8}{|c|}{ Germany } \\
\hline & 2010 & 2011 & 2012 & 2013 & 2014 & 2015 & Total \\
\hline Medicine & 0 & 0 & 1 & 2 & 2 & 0 & 5 \\
\hline Energy & 0 & 2 & 2 & 1 & 1 & 4 & 10 \\
\hline Environment & 1 & 0 & 0 & 0 & 0 & 0 & 1 \\
\hline Total & 1 & 2 & 3 & 3 & 3 & 4 & 16 \\
\hline
\end{tabular}

When patents from the countries are compared separately for each category, as shown in figures 12, 13 and 14 , further information can be extracted on the trends in each country. More specifically, it can be seen that although the US clearly has the most Medicine related patents, the rest of the countries do not appear as active in the area, even though the numbers are high in Taiwan and Germany as well. When it comes to Energy, the US has the most patents among all the other countries, and the amount has been increasing consistently the past number of years. Japan follows the same trend, while Korea, Taiwan and Germany remain at lower levels. When it comes to the Environment patents, it becomes obvious that there is a general disinterest from most countries in the past couple of years, though the US did publish some, even if the number is not comparable to the other two categories.

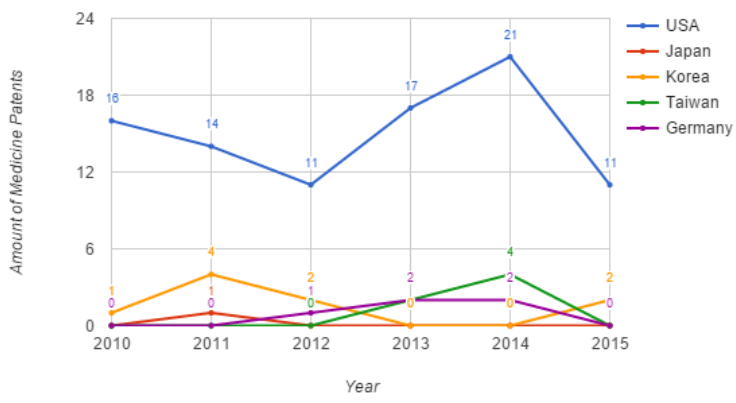

Fig.12. Amount of Medicine Patents per year and country 


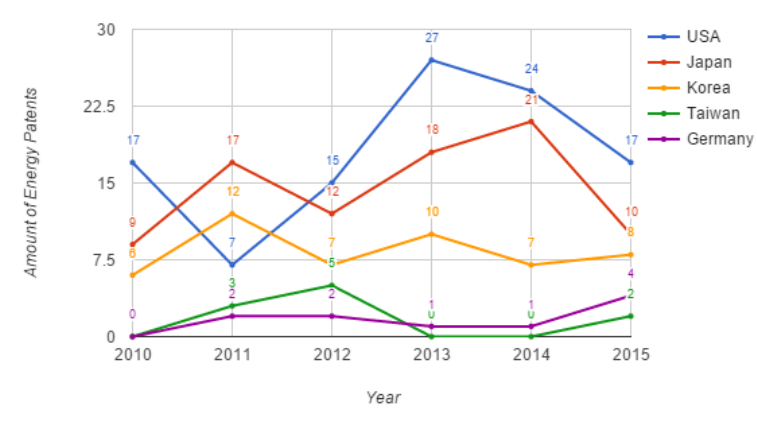

Fig. 13. Amount of Energy Patents per year and country

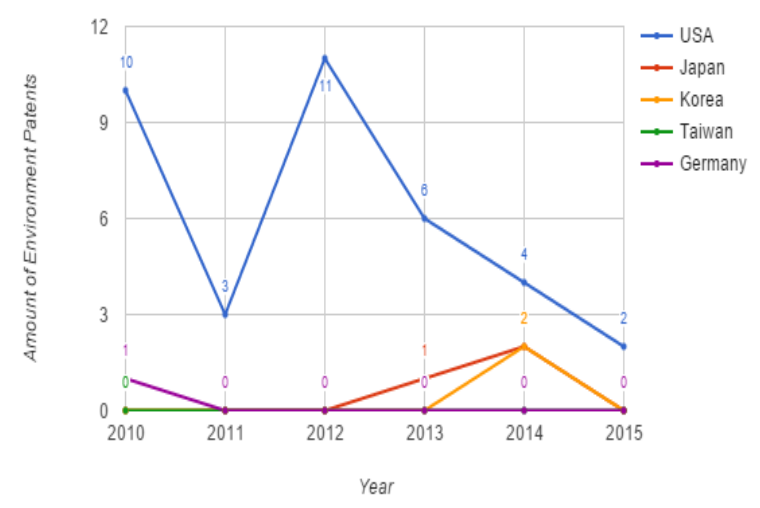

Fig. 14. Amount of Environment Patents per year and country

It appears that the US holds the most patents in total, followed at a distance by Japan and then Korea. The US and Korea lead the way in Medicine related patents, while for the Environmental ones, only the US appears to be active enough in the field.

\section{Literature Intensity}

Literature is often correlated with patents, therefore a Scopus database search was also conducted in order to verify the relation and better identify the innovation trends. The terms used were the same as the ones for the patents, i.e. mesoporous, macroporous, microporous, nanoporous and porous, studying the amounts of results per year and per category (Energy, Medicine, Environment), starting from 2011 up to October of 2015.

The results presented in figures 15 and 16 clearly show that most of the literature found focused on Energy related matters, at an incremental trend over the years. The Environment related literature was far behind that and the Medicine related one was even more limited. It is interesting to note that while there are more Medicine related patents than Environment ones, the literature for the Environmental issues are significantly more substantial than that for Medicine (figure 15).

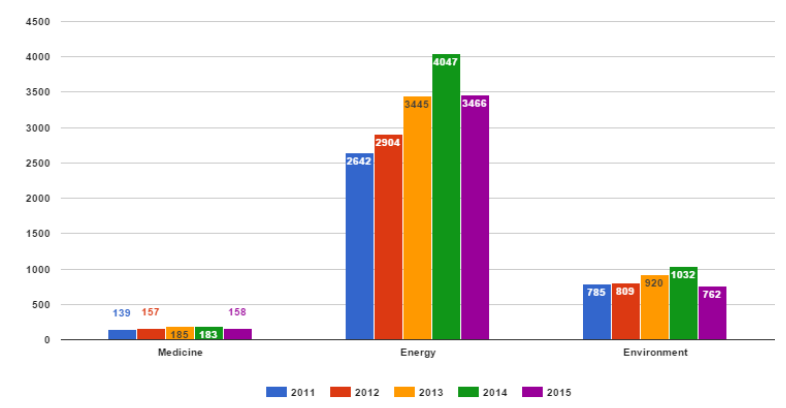

Fig. 15. Literature by category and year as found on the Scopus database

Furthermore, when the results are compared based on the pore size of the material, it is evident that about $67 \%$ of the results are related to the more general term "porous", which is far more than the amount of all the other terms combined. The term "microporous" follows right after with about 17\%, while the term "nanoporous" appears in about $8 \%$ of the results (Figure 16).

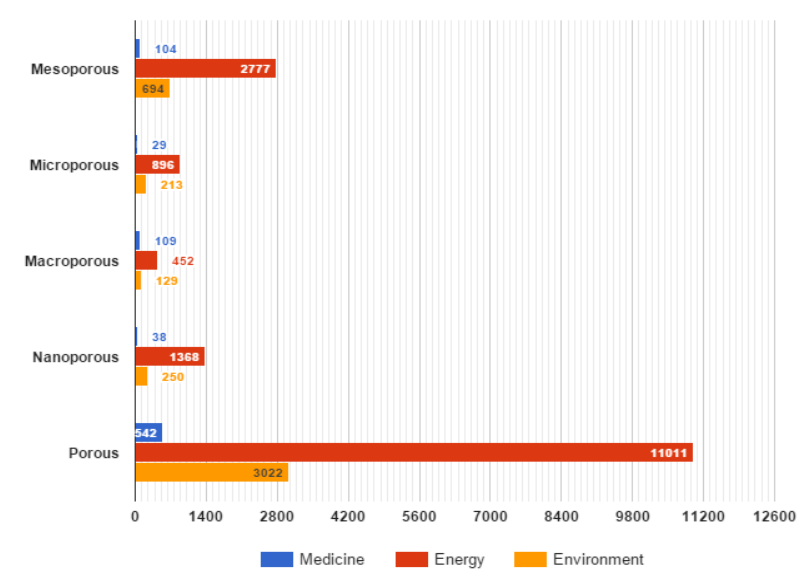

Fig. 16. Literature by category and material pore size as found on the Scopus database

\section{General Conclusions}

Patent statistics offer the means for analysing trends, opportunities and gaps in a specific field [23-30]. Despite the fact that patent data is mainly ex post information, that does not by default represent the current status of a technology, patents do have a 20-year lifecycle, therefore the competitive status of stakeholders could still be estimated for a certain time period. Data mining and statistical methods have been used to analyse the patent data, aiming to discover new information.

The research described in this paper was focused on finding patents utilizing nanoporous materials in Energy, Medicine, and Environment, and analysing the characteristics of those patents in order to identify trends and opportunities over recent years. In addition, the quality and value of such patents based on a set of criteria has also been discussed.

The results suggest that only a modest portion of patents receives forward citations by other patents so far, though USPTO patents generally have more than the EPO ones. The 
higher amount in USPTO indicates that those patent holders might be more active in their area of expertise or that the cited patents might be more significant in their field, acting as a guide for other patented applications. Almost $64 \%$ of the USPTO patents have $10+$ references to other patents. It is also indicated that the majority of the patents with significant amount of backwards citations are Energyrelated, followed by those patents in the Environment category. For the EPO patents, they appear to be far less. The difference between USPTO and EPO patents is an indication that the USPTO patent holders made more extensive research on prior art. USPTO patents appear to focus mostly on Energy applications, while those in Medicine and Environment have become slightly less popular in the past half year. For EPO, the results are similar for the energy patents, though the Environment-related ones have a very low presence. The patent family analysis shows that the majority of patents in both offices belong in a family of 1 to 10 members. USPTO patents tend to have more family members in general. The generic microporous membranes and the microporous polyolefin membranes are the most referenced materials in total, followed by microporous polymers and mesoporous silica. The US, followed closely by Japan, is the leader when it comes to Energy patents. The US and Korea lead the way in Medicine-related patents, while for the US appears to be the only country with significant amount of Environment-related patents. A literature review via a Scopus database search confirms that Energy related literature surpasses those in other categories by a distance. There is a difference between the patent trends and the literature trends when it comes to the Environment and Medicine categories. While Environment related patents are limited in number and show slower development trends than the Medicine related patents, the amount of literature on Environment related matters exceeds that of the Medicine related.

\section{References}

1. G. Q. Lu and X. S. Zhao, Eds., Nanoporous materials: science and engineering. London: Imperial College Press, 2004.

2. M. Rehakova, A. Sopkova, and J. Lokaj, "Natural zeolitic material of the clinoptilolite type doped with iodine and its ions," J. Incl. Phenom. Mol. Recognit. Chem., vol. 14, no. 1, pp. 47-54, Sep. 1992.

3. D. Verboekend, T. C. Keller, M. Milina, R. Hauert, and J. Pérez-Ramírez, "Hierarchy Brings Function: Mesoporous Clinoptilolite and L Zeolite Catalysts Synthesized by Tandem Acid-Base Treatments," Chem. Mater., vol. 25, no. 9, pp. 1947-1959, May 2013.

4. V. Meynen, P. Cool, and E. F. Vansant, "Verified syntheses of mesoporous materials," Microporous Mesoporous Mater., vol. 125, no. 3, pp. 170-223, Oct. 2009.

5. E. Vansant, A. Mitropoulos, and J. Nolan, Exciting Nanoporous Materials Fundamentals, Characterisation, Applications and Trends. Saarbrücken: LAP LAMBERT Academic Publishing, 2015.

6. C. A. Cooper and Y. S. Lin, "Microstructural and gas separation properties of CVD modified mesoporous $Y$ alumina membranes," J. Membr. Sci., vol. 195, no. 1, pp. 3550, Jan. 2002.

7. S. Bhattacharyya, Y. Mastai, R. Narayan Panda, S.-H. Yeon, and M. Z. Hu, "Advanced Nanoporous Materials: Synthesis, Properties, and Applications," J. Nanomater., vol. 2014, pp. 1-2, 2014.

8. "PATSTAT Online (Beta)," European Patent Office, 09-Jun$2015 . \quad$ [Online]. Available: http://www.epo.org/searching/subscription/patstatonline.html. [Accessed: 01-Jul-2015].

9. "Identifying Technology Spillovers and Product Market Rivalry," Econometrica, vol. 81, no. 4, pp. 1347-1393, 2013.

10. N. van Zeebroeck, "The puzzle of patent value indicators," Econ. Innov. New Technol., vol. 20, no. 1, pp. 33-62, Jan. 2011.

11. H. Park, J. J. Ree, and K. Kim, "Identification of promising patents for technology transfers using TRIZ evolution trends," Expert Syst. Appl., vol. 40, no. 2, pp. 736-743, Feb. 2013.

12. Y. Geum, S. Lee, B. Yoon, and Y. Park, "Identifying and evaluating strategic partners for collaborative R\&amp;D: Index-based approach using patents and publications," Technovation, vol. 33, no. 6-7, pp. 211-224, Jun. 2013.

13. S.-S. Park, W.-G. Jung, Y.-G. Shin, and D.-S. Jang, "A patent examining expert system using pattern recognition," Expert Syst. Appl., vol. 38, no. 4, pp. 4302-4311, Apr. 2011.

14. "Kind codes," European Patent Register. .

15. "World Intellectual Property Organization," Member States. [Online]. Available: http://www.wipo.int/members/en/. [Accessed: 27-Jun-2015].
16. "Maintenance fee," Wikipedia.

17. "Valuation Methodology," ValueMyPatent. [Online]. Available: http://www.valuemypatent.com/Methodology.aspx. [Accessed: 28-Jul-2015].

18. "Patent families," European Patent Office, 29-Oct-2010. [Online]. Available: http://www.epo.org/searching/essentials/patent-families.html. [Accessed: 10-Jul-2015].

19. "Key Enabling Technologies," European Commission Growth Industry Key Enabling Technologies, 10-Jun-2015. [Online]. Available: http://ec.europa.eu/growth/industry/key-enablingtechnologies/index_en.htm. [Accessed: 10-Jul-2015].

20. "Manufacturing and control of nanoporous materials (NMP 3 - 2015)," Horizon 2020. [Online]. Available: http://www.2020horizon.com/Manufacturing-and-control-of-nanoporousmaterials-i1544.html. [Accessed: 15-Jul-2015].

21. M. C. Roco, "The Long View of Nanotechnology Development: The National Nanotechnology Initiative at 10 Years," in Nanotechnology Research Directions for Societal Needs in 2020, Dordrecht: Springer Netherlands, 2011, pp. $1-28$.

22. V. Mangematin and S. Walsh, "The future of nanotechnologies," Technovation, vol. 32 , no. 3-4, pp. 157160, Mar. 2012.

23. Shapira, P., Youtie, J., \& Arora, S. (2012). Early patterns of commercial activity in graphene. Journal of Nanoparticle Research, 14(4), 1-15.

24. Nagaoka, S., Motohashi, K., \& Goto, A. (2010). Patent statistics as an innovation indicator. In B. H. Hall \& N. Rosenberg (Eds.), Handbook of the Economics of Innovation (pp. 1083-1127). Oxford, UK: Elsevier.

25. Kay, L., Youtie, J., Porter, A. L., Rafols, I., \& Newman, N. (2014). Patent overlay mapping: Visualizing technological distance. Journal of the Association for Information Science and Technology, 65(12), 2432-2443.

26. Albert, M., Avery, D., Narin, F., \& McAllister, P. (1991). Direct validation of citation counts as indicators of industrially important patents. Research Policy, 20(3), 251-259.

27. Leydesdorff, L., Alkemade, F., Heimeriks, G., \& Hoekstra, R. (2015). Patents as instruments for exploring innovation dynamics: geographic and technological perspectives on "photovoltaic cells". Scientometrics, 102(1), 629-651.

28. Hall, B. H., Jaffe, A., \& Trajtenberg, M. (2005). Market value and patent citations. The Rand Journal of Economics, 36(1), 16-38.

29. Trajtenberg, M. (1990). A penny for your quotes: Patent citations and the value of innovations. The Rand Journal of Economics, 21(1), 172-187. 
Annex 1

\begin{tabular}{|c|c|c|c|c|}
\hline \# & CPC group & Patents & CPC Description & Ranking (\%) \\
\hline 1 & Y10T428 & 807 & $\begin{array}{l}\text { Stock material or miscellaneous articles } \\
\text { Enabling technologies or technologies with a potential or indirect contribution to }\end{array}$ & 8.82 \\
\hline 2 & Y02E60 & 619 & GHG emissions mitigation & 6.76 \\
\hline 3 & H01M2 & 603 & $\begin{array}{l}\text { Constructional details or processes of manufacture of the non-active parts } \\
\text { Semi-permeable membranes for separation processes or apparatus characterised }\end{array}$ & 6.59 \\
\hline 4 & B01D71 & 529 & $\begin{array}{l}\text { by the material; Manufacturing processes specially adapted therefor } \\
\text { Processes specially adapted for manufacturing semi-permeable membranes for }\end{array}$ & 5.78 \\
\hline 5 & B01D67 & 457 & separation processes or apparatus & 4.99 \\
\hline 6 & H01M10 & 427 & $\begin{array}{l}\text { Secondary cells; Manufacture thereof } \\
\text { Semi-permeable membranes for separation processes or apparatus characterised } \\
\text { by their form, structure or properties; Manufacturing processes specially adapted }\end{array}$ & 4.67 \\
\hline 7 & B01D69 & 424 & therefor & 4.63 \\
\hline 8 & B01D2325 & 400 & Details relating to properties of membranes & 4.37 \\
\hline 9 & B01J29 & 308 & Catalysts comprising molecular sieves & 3.37 \\
\hline 10 & B01D2323 & 294 & Details relating to membrane preparation & 3.21 \\
\hline 12 & B01J35 & 248 & $\begin{array}{l}\text { Catalysts, in general, characterised by their form or physical properties } \\
\text { Manufacture of articles or shaped materials containing macromolecular } \\
\text { substances (shaping of foodstuffs A23P; manufacture of semi-permeable } \\
\text { membranes B01D67/00 to B01D71/00; mechanical features, see the relevant } \\
\text { classes, e.g. B29) } \\
\text { Solid sorbent compositions or filter aid compositions; Sorbents for }\end{array}$ & 2.71 \\
\hline 13 & $\mathrm{~B} 01 \mathrm{~J} 20$ & 244 & $\begin{array}{l}\text { chromatography; Processes for preparing, regenerating or reactivating thereof } \\
\text { Processes, in general, for preparing catalysts; Processes, in general, for activation }\end{array}$ & 2.67 \\
\hline 14 & B01J37 & 238 & of catalysts & 2.6 \\
\hline 15 & $\mathrm{~B} 82 \mathrm{Y} 30$ & 227 & $\begin{array}{l}\text { Nano-technology for materials or surface science, e.g. nano-composites } \\
\text { Layered products comprising a layer of synthetic resin (B32B5/02, B32B5/16, }\end{array}$ & 2.48 \\
\hline 16 & B32B27 & 226 & $\begin{array}{l}\text { B32B } 5 / 18 \text { take precedence; thermoplastic elastomer B32B } 2274 / 00 \text { ) } \\
\text { Characterised by the use of homopolymers or copolymers of unsaturated } \\
\text { aliphatic hydrocarbons having only one carbon-to-carbon double bond; } \\
\text { Derivatives of such polymers }\end{array}$ & 2.47 \\
\hline 18 & B29K2105 & 211 & $\begin{array}{l}\text { Condition, form or state of moulded material or of the material to be shaped } \\
\text { Shaping by stretching, e.g. drawing through a die; Apparatus therefor }\end{array}$ & 2.31 \\
\hline 19 & B01D53 & 182 & $\begin{array}{l}\text { (B29C61/08 takes precedence) } \\
\text { Separation of gases or vapours; Recovering vapours of volatile solvents from } \\
\text { gases; Chemical or biological purification of waste gases, e.g. engine exhaust } \\
\text { gases, smoke, fumes, flue gases, aerosols }\end{array}$ & 2.22 \\
\hline 21 & H01M4 & 181 & $\begin{array}{l}\text { Electrodes (electrodes for electrolytic processes } \mathrm{C} 25 \text {, electrodes for hybrid or } \\
\text { electric double capacitor H01G11/22) } \\
\text { Catalysts comprising metals or metal oxides or hydroxides, not provided for in }\end{array}$ & 1.98 \\
\hline 22 & $\mathrm{~B} 01 \mathrm{~J} 23$ & 179 & $\begin{array}{l}\text { group } \\
\text { Compounds having molecular sieve properties but not having base-exchange }\end{array}$ & 1.96 \\
\hline 23 & C01B37 & 171 & $\begin{array}{l}\text { properties } \\
\text { Catalysts comprising the elements, oxides, or hydroxides of magnesium, boron, }\end{array}$ & 1.87 \\
\hline $\begin{array}{l}24 \\
25\end{array}$ & $\begin{array}{l}\mathrm{B} 01 \mathrm{~J} 21 \\
\mathrm{H} 01 \mathrm{M} 8\end{array}$ & $\begin{array}{l}169 \\
168\end{array}$ & $\begin{array}{l}\text { aluminium, carbon, silicon, titanium, zirconium, or hafnium } \\
\text { Fuel cells; Manufacture thereof }\end{array}$ & $\begin{array}{l}1.85 \\
1.84\end{array}$ \\
\hline 26 & B29K2023 & 166 & $\begin{array}{l}\text { Use of polyalkenes or derivatives thereof as moulding material (as such } \\
\text { C08L23/00) }\end{array}$ & 1.81 \\
\hline 27 & B01J2229 & 162 & $\begin{array}{l}\text { Aspects of molecular sieve catalysts not covered by } \mathrm{B} 01 \mathrm{~J} 29 / 00 \\
\text { Compounds having molecular sieve and base-exchange properties, e.g. } \\
\text { crystalline zeolites; Their preparation; After-treatment, e.g. ion-exchange or } \\
\text { dealumination (treatment to modify the sorption properties, e.g. shaping using a } \\
\text { binder, B01J20/10; treatment to modify the catalytic properties, e.g. combination } \\
\text { of treatments to make the zeolites appropriate to their use as a catalyst, } \\
\text { B01J29/04; treatment to improve the ion-exchange properties B01J39/14; } \\
\text { regeneration or reactivation of ion-exchange properties B01J49/00; preparation }\end{array}$ & 1.77 \\
\hline 29 & C01B39 & 154 & $\begin{array}{l}\text { of stabilised suspensions used in detergents C11D3/12) } \\
\text { Working-up of macromolecular substances to porous or cellular articles or } \\
\text { materials; After-treatment thereof (mechanical aspects B29C44/00; foamed } \\
\text { polymeric products of isocyanates or isothiocyanates characterised by the } \\
\text { monomers or catalysts used C08G18/00) } \\
\text { Technologies for wastewater treatment (fuel from waste Y02E50/30; methane }\end{array}$ & 1.68 \\
\hline 30 & Y02W10 & 147 & $\begin{array}{l}\text { from waste for energy generation } \mathrm{Y} 02 \mathrm{E} 50 / 34) \\
\text { Treatment of water, waste water, or sewage }(\mathrm{C} 02 \mathrm{~F} 3 / 00 \text { to } \mathrm{C} 02 \mathrm{~F} 9 / 00 \text { take }\end{array}$ & 1.61 \\
\hline $\begin{array}{l}31 \\
32\end{array}$ & $\begin{array}{l}\text { C02F1 } \\
\text { Y02T10 }\end{array}$ & $\begin{array}{l}131 \\
128\end{array}$ & $\begin{array}{l}\text { precedence) } \\
\text { Road transport of goods or passengers }\end{array}$ & $\begin{array}{l}1.43 \\
1.4\end{array}$ \\
\hline 33 & B32B5 & 118 & $\begin{array}{l}\text { Layered products characterised by the non- homogeneity or physical structure, } \\
\text { i.e. comprising a fibrous, filamentary, particulate or foam layer; Layered } \\
\text { products characterised by having a layer differing constitutionally or physically } \\
\text { in different parts } \\
\text { Processes of separation using semi-permeable membranes, e.g. dialysis, osmosis, }\end{array}$ & 1.29 \\
\hline 34 & B01D61 & 117 & ultrafiltration; Apparatus, accessories or auxiliary operations specially adapted & 1.28 \\
\hline
\end{tabular}


D. A. Gkika, C. Kontogoulidou, J. W. Nolan, A. Ch. Mitropoulos, E. F. Vansant, P. Cool and J. Braet Journal of Engineering Science and Technology Review 9 (5) (2016) 24 - 35

there for

Compositions of homopolymers or copolymers of unsaturated aliphatic hydrocarbons having only one carbon-to-carbon double bond; Compositions of derivatives of such polymers

Physical properties of inorganic compounds

Extrusion moulding, i.e. expressing the moulding material through a die or nozzle which imparts the desired form; Apparatus therefor

Carbon; Compounds thereof (C01B6/00, C01B21/00, C01B23/00 take precedence; percarbonates $\mathrm{C} 01 \mathrm{~B} 15 / 10$; carbon black $\mathrm{C} 09 \mathrm{C} 1 / 48$; gas carbon production $\mathrm{C} 10 \mathrm{~B}$ )

Nanotechnology

Mortars, concrete or artificial stone or mixtures to prepare them, characterised by specific function, property or use

Components to be removed

Products obtained by processes covered by groups C10G9/00 to C10G69/14

Electrolytic capacitors, rectifiers, detectors, switching devices, light-sensitive or temperature-sensitive devices; Processes of their manufacture

Medicinal preparations characterised by special physical form (nuclear magnetic resonance contrast preparations or magnetic resonance imaging contrast preparations A61K49/18; preparations containing radioactive substances A $61 \mathrm{~K} 51 / 12$

Materials for grafts or (dental prostheses $\mathrm{A} 61 \mathrm{C} 13 / 00$; shape or structure of prostheses A61F2/00; use of preparations for artificial teeth A61K6/02; artificial kidneys A61M1/14) prostheses or for coating grafts or prostheses

Aspects relating to hydrocarbon processing covered by groups C10G1/00 C10G99/00

Shaped ceramic products characterised by their composition (porous ceramic products C04B38/00; ceramic articles characterised by particular shape, see the relevant classes, e.g. linings for casting ladles, tundishes, cups or the like B22D41/02; ceramic substrates for microelectronic semi-conductors H01L23/15); Ceramics compositions (containing free metal bonded to carbides, diamond, oxides, borides, nitrides, silicides, e.g. cermets, or other metal compounds, e.g. oxynitrides or sulfides other than as macroscopic reinforcing agents $\mathrm{C} 22 \mathrm{C}$; shaping of ceramics B28B); Processing powders of inorganic compounds preparatory to the manufacturing of ceramic products (Chemical preparation of powders of inorganic compounds $\mathrm{C} 01$; infiltration of sintered ceramic preforms with molten metal C04B41/51)

Silicon; Compounds thereof (C01B6/00, C01B21/00, C01B23/00 take \begin{tabular}{l|l} 
precedence; persilicates $\mathrm{C} 01 \mathrm{~B} 15 / 14$; carbides $\mathrm{C} 01 \mathrm{~B} 31 / 36)$ & 0.87
\end{tabular} Properties of the layers or laminate

Investigating or analysing materials by specific methods not covered by the preceding groups 